\title{
The Efficient Solubilization and Refolding of Recombinant Organophosphorus Hydrolyses Inclusion Bodies Produced in Escherichia coli
}

\author{
Seyed Ali Mirhosseini ${ }^{1}$, Ali Mohammad Latifi ${ }^{2}$, Hamideh Mahmoodzadeh Hosseini ${ }^{1}$, Rezvan Seidmoradi ${ }^{3}$, Hossein \\ Aghamollaei $^{4}$, Gholamreza Farnoosh ${ }^{* 2}$ \\ ${ }^{1}$ Applied Microbiology Research Center, Systems Biology and Poisonings Institute, Baqiyatallah University of Medical Sciences, \\ Tehran, Iran \\ ${ }^{2}$ Applied Biotechnology Research Center, Systems Biology and Poisonings Institute, Baqiyatallah University of Medical Sciences, \\ Tehran, Iran \\ ${ }^{3}$ Faculty of Biological Science, Alzahra University, Tehran, Iran \\ ${ }^{4}$ Chemical Injuries Research Center, Systems Biology and Poisonings Institute, Baqiyatallah University of Medical Sciences, Tehran, \\ Iran
}

Corresponding Author: Gholamreza Farnoosh, PhD, Assistant Professor, Applied Biotechnology Research Centre, Baqiyatallah University of Medical Sciences, Tehran, Iran. Tel/Fax:+98-2177104110, Email: rzfarnoosh@yahoo.com

Received September 7, 2018; Accepted February 11, 2019; Online Published March 15, 2019

\begin{abstract}
Introduction: Organophosphorus hydrolase (OPH) is an enzyme that can degrade organophosphorus compounds in pesticides. High expression levels of OPH in Escherichia coli lead to form inclusion body in cytoplasmic space which is an inactive form of protein and needs a solubilizing and refolding process. The aim of this study was to compare different methods for solubilization and refolding of recombinant OPH expressed in $E$. coli. Materials and Methods: OPH was expressed in E. coli and purified by the Ni-NTA column. The refolding efficiency of this protein was assessed by 4 strategies: dialysis, rapid dilution, on column and combination of rapid dilution and dialysis. In each case, the refolding efficiency was evaluated by SDS-PAGE analysis and enzyme activity assay and was compared to find the best procedure.

Results: The refolding efficiency of these 4 strategies was estimated at about $12 \%, 10 \%, 14 \%$ and $50 \%$ for on column, rapid dilution, dialysis and combination of rapid dilution and dialysis, respectively. Results showed that during the refolding process, most proteins did not reach the correct structure and aggregated again while the combination of 2 methods, rapid dilution and dialysis provided an appropriate procedure to refold. Conclusions: The combination of rapid dilution and dialysis is an efficient method for refolding OPH. The efficacy of this method for refolding other recombinant proteins can be further investigated.

Keywords: Organophosphorus Hydrolases, Inclusion Bodies, Solubilization, Refolding, Protein Activity

Citation: Mirhosseini SA, Latifi AM, Mahmoodzadeh Hosseini H, Seidmoradi R, Aghamollaei H, Farnoosh G. The efficient solubilization and refolding of recombinant organophosphorus hydrolyses inclusion bodies produced in E. coli. J Appl Biotechnol Rep. 2019;6(1):20-20. doi:10.29252/JABR.06.01.04.
\end{abstract}

\begin{abstract}
Introduction
Escherichia coli is a known host to produce recombinant proteins without post translational modification. Although this system is the facile and rapid model for genetic engineering and biotechnological purposes, the accumulation and aggregation of proteins owing to high level expression is its momentous disadvantage. ${ }^{1,2}$ After protein aggregations, named inclusion bodies, the biological activity of recombinant proteins loses therefore, it is necessary to restore the bioactivity of expressed proteins via solubilization and refolding. ${ }^{3,4}$ Various denaturant compounds including guanidine hydrochloride and urea along with $\beta$-mercaptoethanol and other reducing materials are routinely applied to solubilize inclusion bodies and then refold the protein by removal denaturant compounds. ${ }^{4,5}$ In
\end{abstract}

spite of the described disadvantage, producing inclusion bodies have advantages in research and industrial fields including high level expression, ease of purification, decrease of degradation due to resistance to enzymatic effects and so on. ${ }^{6}$ However, efficient protocols and procedures for recovery of high yield bioactive recombinant proteins are needed. Refolding is still the difficult step of purification. Three procedures are commonly used to refold the inclusion bodies; dialysis, dilution and column. Although all three methods have several advantages and disadvantages, but without going into details of each, rapid dilution would be recommended. ${ }^{7}$ Rapid dilution is the facile to do and immediately comes to the final refolding step. Furthermore, it is a reproducible method., ${ }^{3,8}$ Dialysis, as a refolding protocol, has some drawbacks such

Copyright $\odot 2019$ The Author(s). This is an open-access article distributed under the terms of the Creative Commons Attribution License (http:// creativecommons.org/licenses/by/4.0), which permits unrestricted use, distribution, and reproduction in any medium, provided the original work is properly cited. 
as slow rates of denaturant removal and the presence of aggregations because of stable intermediates in prolonged times. To enhance the quantity of bioactive proteins from inclusion body, discrepant dialysis and dilution procedure were introduced along with the use of additives. ${ }^{5,8} \mathrm{~L}$-arginine, urea (1-2 M), guanidine hydrochloride and detergents are the most routinely used additives. ${ }^{9}$ Recently, efforts have been made to improve high-throughput refolding methods for achieving high yield of refold bioactive proteins. ${ }^{3,10}$

The $\mathrm{OPH}$ is the homodimer hydrolase enzyme with molecule weight of $72 \mathrm{kDa}$ that is produces by Pseudomonas and Flavobacterium bacterium. This enzyme degrades the wide range of organophosphorus compounds. ${ }^{10}$ This enzyme is the metalloprotein and its active site contains 2 cations. The presence of cations particularly central $\mathrm{Zn}^{2+}$ and $\mathrm{Co}^{2+}$ causes augment stability and catalytic activity of enzyme, respectively. ${ }^{10,11}$ The $\mathrm{OPH}$ can hydrolyze phosphodiester, phosphonofloride, phosphorothioate and phosphoroamidocyanide bonds in various substrates such as paraoxon, sarin, soman, VX, P-CN and tabun. ${ }^{10}$ To provide a high quantity of $\mathrm{OPH}$, several cloning systems including Escherichia coli, Drosophila melanogaster, Pichia pastoris, Streptomyces lividans, insect cells Serratia, Arthrobacter, Enterobacter, Burkholderia, Flavobacterium and Pseudomonas diminuta were applied to express this enzyme. In addition, several attempts were made to improve the catalytic activity of the recombinant enzyme. ${ }^{10-12}$ Regarding the different impacts of refolding methods and additives on the renaturing and folding proteins, the current study assessed the discrepant methods and compounds for solubilization and refolding of recombinant $\mathrm{OPH}$.

\section{Materials and Methods}

Culture and Protein Overexpression

To produce the OPH enzyme, the plasmid pET32a containing the oph gene was transformed into E. coli Rosetta-gami. A single colony was selected and inoculated into $5 \mathrm{~mL}$ Luria Bertani broth (LB) (Sigma-Aldrich, Germany) containing $100 \mathrm{mg} / \mathrm{mL}$ ampicillin. After being shaken overnight with a culture tube at $37^{\circ} \mathrm{C}$ at $200 \mathrm{rpm}, 1 \%$ of primary inoculum was added to $1 \mathrm{~L}$ fresh LB broth (amp+) and was grown at $37^{\circ} \mathrm{C}$ with vigorous shaking until the optical density of culture medium at $600 \mathrm{~nm}$ reached to 0.8 . After on, 0.5 mM Isopropylb-D-1-thiogalactopyranoside (IPTG) (SigmaAldrich, Germany) was added to the culture medium and incubated under similar conditions for 12 hours. ${ }^{13}$

\section{Inclusion Body Isolation and Solubilization}

To provide the inclusion bodies, bacterial cells were sonicated in resuspension buffer containing $50 \mathrm{mM}$ Tris/pH 8.0/1 mM EDTA/10\% Glycerol, $200 \mathrm{mM}$ PMSF, 10 times with 30 -second pulses on ice, and centrifuged at $9000 \times \mathrm{g}$ for 30 minutes at $4^{\circ} \mathrm{C}$. The inclusion body pellet was washed three times with washing buffer (RNase A, $50 \mathrm{mM} \mathrm{PBS/pH} \mathrm{7.4/1}$ $\mathrm{mM}$ EDTA) and further with buffer containing $2 \mathrm{M}$ urea and then centrifuged at $9000^{\times} \mathrm{g}$ for 30 minutes (13). Next, the lysis buffer A (20 mM Tris-Cl, pH 8.0, $10 \mathrm{mM} \mathrm{NaCl}, 0.1 \mathrm{mM}$ phenylmethanesulfonyl fluoride, $0.1 \mathrm{mM}$ EDTA, and $1 \mathrm{mM}$ 2-mercaptoethanol) was added to pellet and was centrifuged at $47000 \times \mathrm{g}$ for 1 hour. ${ }^{14}$

\section{Purification via Ni-NTA Affinity Chromatography}

One milliliter of Ni-NTA resin (Qiagen, Chatsworth, CA) was packed into a syringe under gravity and washed and equilibrated in $3 \mathrm{~mL}$ deionized water followed by $3 \mathrm{~mL}$ binding buffer ( $5 \mathrm{mM}$ imidazole, $0.5 \mathrm{M} \mathrm{NaCl}, 20 \mathrm{mM}$ Tris$\mathrm{HCl}, \mathrm{pH} 7.9$ ) containing $6 \mathrm{M}$ urea. Pellet from a $250 \mathrm{~mL}$ culture were suspended in $40 \mathrm{~mL}$ binding buffer. Solubilized inclusion bodies were filtered through a $0.45-\mathrm{mm}$ membrane and applied to the Ni-NTA column at room temperature. The column was washed with 10 volume of binding buffer containing $6 \mathrm{M}$ urea and 6 volume of wash buffer $(20 \mathrm{mM}$ imidazole, $0.5 \mathrm{M} \mathrm{NaCl}, 20 \mathrm{mM}$ Tris- $\mathrm{HCl}, \mathrm{pH}$ 7.9) containing $6 \mathrm{M}$ urea. The bound protein was eluted with $500 \mathrm{mM}$ imidazole, $0.5 \mathrm{M} \mathrm{NaCl}, 20 \mathrm{mM}$ Tris- $\mathrm{HCl}(\mathrm{pH}$ 7.9) containing $6 \mathrm{M}$ urea. One-milliliter fractions were collected and monitored by protein dye-binding assay.

\section{Refolding}

To select the best method for protein refolding, 4 procedures including refolding on column, rapid dilution, dialysis and combination of dialysis and dilution were performed.

\section{Refolding on Column}

In this procedure, isolation and refolding was performed simultaneously. For this purpose, the column was washed with urea gradient from 8 to 0 with solution containing 20 $\mathrm{mM}$ Tris- $\mathrm{HCl}, \mathrm{pH} 8 ; 100 \mathrm{mM} \mathrm{NaH}_{2} \mathrm{PO} 4,20 \mathrm{mM}$ imidazole, 1 $\mathrm{mM}$ Oxidized glutathione, $5 \mathrm{mM}$ reduced glutathione and 50 $\mathrm{mM} \mathrm{NaCl}$. At the final step, the purification of protein was done using a solution containing 150 and $200 \mathrm{mM}$ imidazole without urea. To remove additional compounds, refolded proteins were dialyzed with $20 \mathrm{mM}$ Tris- $\mathrm{HCl}, \mathrm{pH}$ 8. Finally, the dialyzed proteins were centrifuged at $12000 \mathrm{rpm}$ for 15 minutes.

\section{Refolding via Dialysis}

To perform this procedure, the isolated proteins were poured to a dialysis bag with cutoff of $12 \mathrm{kDa}$ and were then transferred to the refolding solution $(50 \mathrm{mM}$ Tris- $\mathrm{HCl}, \mathrm{pH} 8$, $50 \mathrm{mM} \mathrm{NaCl}, 1 \mathrm{mM}$ oxidized glutathione and $5 \mathrm{mM}$ Reduced glutathione) and dialyzed in 5 steps with urea gradient including 7, 5, 3, 2 and 0M. Each step was done for 24 hours at $4^{\circ} \mathrm{C}$ on magnet stirrer. After on, the dialyzed proteins were centrifuged at $12000 \mathrm{rpm}$ for 15 minutes.

\section{Refolding via Rapid Dilution}

In this procedure, purified proteins were added to high amounts of buffer (1M urea, $50 \mathrm{mM}$ Tris- $\mathrm{HCl}, \mathrm{pH} 8,50$ $\mathrm{mM} \mathrm{NaCl}, 5 \%$ Glycerol, 0.5M L-argenin, $1 \mathrm{mM}$ oxidized glutathione and $5 \mathrm{mM}$ reduced glutathione). The presence of urea and other compounds prevent rapid and inappropriate folding and precipitation of proteins.

Refolding via Combination of Dialysis and Dilution This method, which is in fact a modified method and has 
been used for the first time in this study, is a combination of 2 methods; dialysis and rapid dilution. For this purpose, the isolated proteins were poured to a dialysis bag with cutoff of $12 \mathrm{kDa}$ and were then dialyzed in the refolding solution for 48 hours at $4^{\circ} \mathrm{C}$ on magnet stirrer. Then, the dialyzed proteins were centrifuged at $12000 \mathrm{rpm}$ for 15 minutes. To remove additional components of refold protein solution, the samples were dialyzed in solution containing buffer (1M urea, $50 \mathrm{mM}$ Tris- $\mathrm{HCl}, \mathrm{pH} 8$ and 5\% glycerol) for 12 hours.

\section{Evaluation of Refolding Products}

SDS-PAGE analysis

To visualize the purified proteins from refolding methods and evaluate the presence of multimers, SDS-PAGE electrophoresis was done. The purified proteins were run on $10 \%$ polyacrylamide gel and then were stained by dye containing 0.1\% Coomassie Brilliant Blue and 12.5\% trichloroacetic acid.

\section{Evaluation of Specific Activity}

To determine the percentage of enzymatic activity of refolded proteins, the specific activity was measured. Briefly, $40 \mu \mathrm{L}$ of each refolded protein, $140 \mu \mathrm{L}$ of Tris- $\mathrm{HCl}$ buffer and $20 \mu \mathrm{L}$ of $20 \mathrm{mM}$ paraoxon (in $20 \%$ deionized water) were mixed. After 10 minutes incubation at $37^{\circ} \mathrm{C}, 100 \mu \mathrm{L}$ of each reaction reagent was transferred to 96 well plate and the generation of $\rho$-Nitrophenol was recorded by assessing optical density at $405 \mathrm{~nm}$ by a spectrophotometer device. Enzyme activity was measured as one micromole of paraoxon hydrolyzed to $\rho$-Nitrophenol per minute, per milliliter. ${ }^{15}$

\section{Results}

Protein Expression and Purification

In spite of the optimizing conditions of time, temperature, and IPTG concentration, most proteins were in the insoluble fraction (Figure 1), so, denaturation refolding was recommended. The purified OPHs were observed as single bands on SDS-PAGE and the molecular mass was estimated as $\sim 47 \mathrm{kDa}$ (Figure 1).

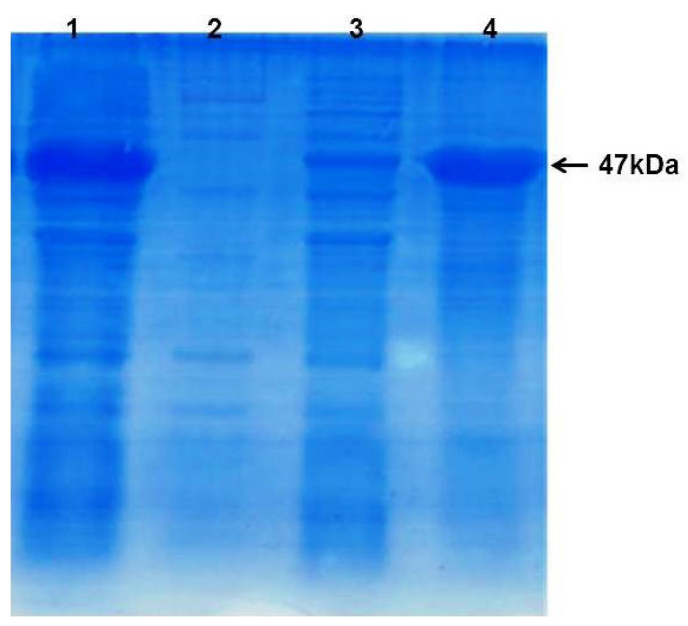

Figure 1. The Purified Recombinant OPH $(\sim 47 \mathrm{kDa})$ by $\mathrm{Ni}+$ Chromatography Column. 1: bacterial pellet; 2: protein marker; 3 : uninduced protein and 4: purified protein induced by IPTG.

\section{Refolding Methods}

In order to select the best procedure for refolding inclusion bodies, 4 methods including dialysis, dilution, $\mathrm{Ni}+$ chromatography column and new modified method comprising dialysis and dilution were compared. Findings revealed that the modified method was the most effective procedure to refold the proteins of inclusion bodies.

\section{Refolding via $\mathrm{Ni}+$ Chromatography Column}

This method is a rapid and affordable owing to simultaneous isolation and refolding. In the current study, the proteins were eluted as a precipitated format. The protein concentration was 500 and $60 \mu \mathrm{g}$ before and after isolation and refolding, respectively (Figure 2 ). The efficiency was $12 \%$.

\section{Refolding via Rapid Dilution}

In this method, although less time is needed, the protein concentration is very low, which causes problems in experiments with high protein concentrations. By this protocol, most proteins were approximately soluble after refolding and centrifugation, but the concentration was very dilute due to the high volume of buffer. The concentration was $50 \mu \mathrm{g} / \mathrm{mL}$ being approximately one tenth of the initial concentration $(500 \mu \mathrm{g} / \mathrm{mL})$ (Figure 3).

\section{Refolding via Dialysis}

This method is the most common protocol, however it is extremely time consuming. In addition, more protein was precipitated in the final stage. As the concentration of urea was $2 \mathrm{M}$, the protein was precipitated, although the protein concentration was reduced to about half $(300 \mu \mathrm{g} / \mathrm{mL}$ ) (Figure 4). After removing urea, the concentration of refolded proteins was about $40 \mu \mathrm{g} / \mathrm{mL}$. The efficiency was also $14 \%$.

\section{Refolding via Combination of Dialysis and Dilution}

In this method, the dilution buffer and dialysis bag were utilized. The disadvantages of both methods, which included being time consuming and having a reduced protein concentration, were eliminated. At the end and after

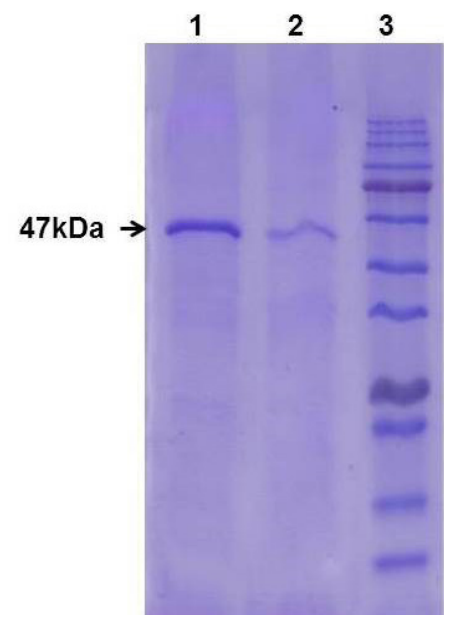

Figure 2. The purified recombinant $\mathrm{OPH}$ refolded by $\mathrm{Ni}+$ chromatography column. 1: protein sample before refolding; 2: protein sample after refolding; 3: protein marker. 


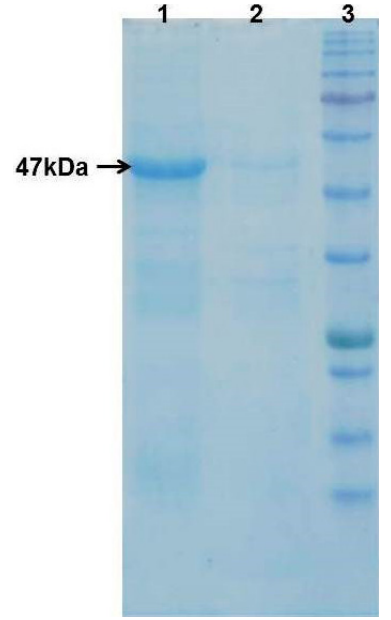

Figure 3. The Purified Recombinant OPH Refolded by Rapid Dilution. 1:protein sample before refolding; 2: protein sample after refolding; 3: protein marker.

centrifugation, the concentration of refolded protein was about $300 \mu \mathrm{g} / \mathrm{mL}$ (Figure 5). The initial concentration of protein was about $500 \mu \mathrm{g} / \mathrm{mL}$. The efficiency of this method was more than 50\% (Figure 6).

\section{Activity Measurements}

Although the relative efficiency of each of these methods is measured by calculating the activity of the enzyme, the purpose of this study was to design an optimal refolding method.

All of the refolded samples were able to degrade paraoxon as a specific substrate. Enzyme activity is calculated based on the paraoxon degradation ability as a specific substrate and p-nitro phenol liberation using spectrophotometer. Observations of the activity was indicated the appropriate enzyme refolding.

\section{Discussion}

The expression of recombinant proteins as the inclusion bodies is the most cost-effective method to produce high level initial proteins. Inclusion bodies isolation in the form of denatured proteins is easy but must refold to bioactive forms. It is confirmed that refolding recombinant proteins from inclusion bodies is the momentous step to effect the product yield. In the routine protocol used in laboratories, the final quantity of bioactive products is very low after refolding. ${ }^{7,16}$ Therefore, designing and improving the refolding method with the high output is necessary for increasing product recovery. In the current study, the OPH enzyme was cloned and expressed in E. coli in the form of inclusion bodies, solubilized and purified by Ni-NTA affinity chromatography. To optimize the refolding procedure for dimer proteins, 4 different methods including dialysis, dilution, $\mathrm{Ni}+$ chromatography column and new modified method comprising dialysis and dilution, were performed and compared. For the first time, the modified method combining dialysis and dilution to recovery about $60 \%$ bioactive refolded proteins from solubilized proteins was used in this study.

It is confirmed that the presence of contaminants such as

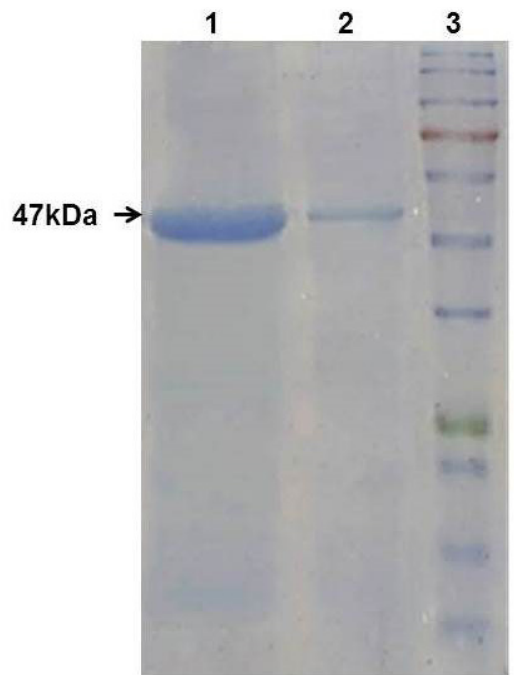

Figure 4. The Purified Recombinant OPH Refolded by Dialysis. 1:protein sample before refolding; 2: protein sample after refolding; 3: protein marker.

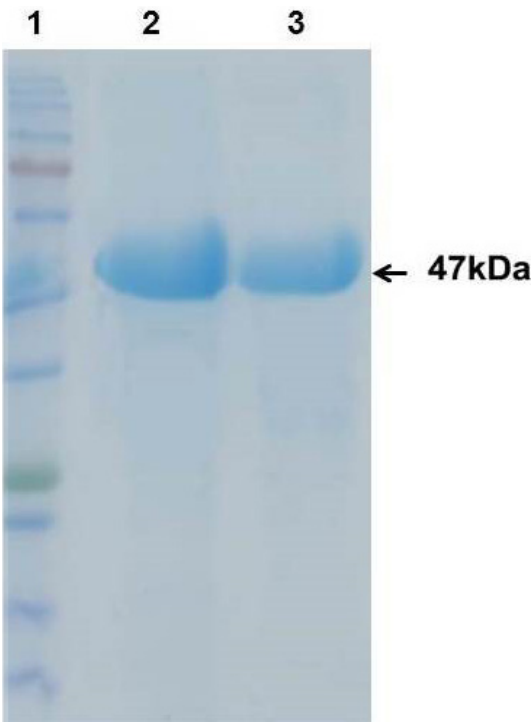

Figure 5. The Purified Recombinant OPH Refolded Via Combination of DIALYSIs and Dilution. 1: protein marker; 2: protein sample before refolding; 3: protein sample after refolding

polypeptide, phospholipid, and bacterial plasmid with the inclusion bodies effects the yield of refolding. ${ }^{7}$ In a study performed by Maachupalli-Reddy et al which examined the impact of contaminants, some actually, the contamination resulted in a higher aggregation and reduction of refolded yield. ${ }^{17}$ In another study, it was observed that reducing and purification of recombinant proteins using reversed-phase chromatography could be useful to substantially augment the quantity of refolded products. ${ }^{18}$ Furthermore, Babbitt et al reported a 100 fold enhancement in the amount of refolded products after eliminating the cell wall contamination by washing with detergents. ${ }^{19}$ In addition, detergent washing is able to increase the yield, in order to remove cell debris from inclusion bodies. ${ }^{20}$ Generally, each method that could remove or decrease any type of contaminants both with lighter or 


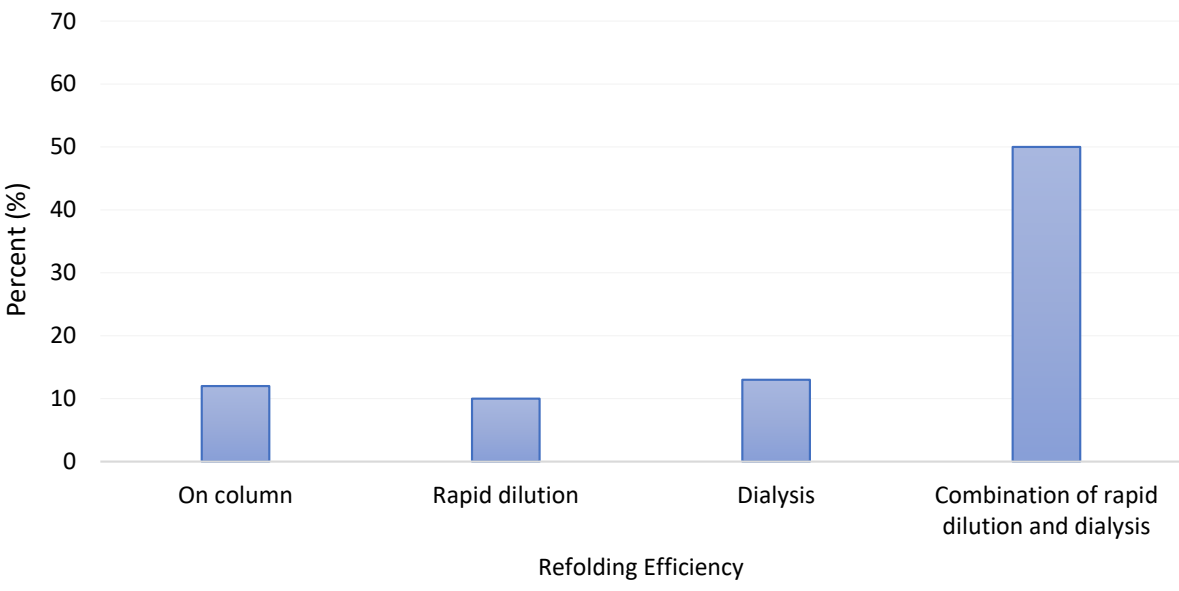

Figure. The Efficiency Percentage of Different Refolding Methods Carried out in This Study.

higher weight and density such as acid nucleic, proteins, cell wall compounds, lipids, outer membrane vesicle, cell debris and so on, enhances the yield of refolded recombinant proteins. ${ }^{21}$ If this method is accessible, facile and affordable, it is useful in all laboratories and for all researchers. The modified method introduced here is the facile protocol to remove the contaminants with the available simple equipment. Moreover, dilution similar column-based methods is used to achieve refolded protein. Dilution is an easy procedure, is facile and also appropriate for sieving redox substances and additives. For example, oxidative chromatography causes to increase the yield of refolded proteins along with combination of renaturing and separation and steps but this column is not cost- effective. ${ }^{21}$

Previous studies applied the centrifugation and membrane filtration in parallel to remove the contaminants of inclusion bodies. Although $45 \%$ to $55 \%$ purity is done in this method via removing cloned gene product, outer membrane vesicle is present, yet..$^{22}$ The homogenisation of expressing bacteria and the size of cell debris are momentous in this method because of possible separations of this impurity with inclusion bodies. ${ }^{20,23}$ In addition, the presence of protease along with inclusion bodies is another disadvantage of centrifugation. ${ }^{24,25}$ Unlike to centrifugation, membrane microfiltration is not a density based method and the impurity with cell debris was not observed. The application of membrane with the pore size of $0.45 \mathrm{~mm}$ resulted in $46 \%$ purity which is lower than centrifugation. ${ }^{26}$

Goldberg et al reported that the diluted protein mixture with low concentration is appropriate to refold efficiently. The refolded efficiency depends on concentration but is not much in the concentration of $1 \mathrm{mg} / \mathrm{mL}^{27}$

Dialysis is a common method to eliminate impurity and remaining reagents from previous steps of protein purification. Concentrating and losing of denatured recombinant proteins through leaking from membranes are the 2 disadvantages of dialysis. ${ }^{28}$ The diminishing effects of impurity on the refolding of recombinant proteins is approved but regardless to the type of contaminants, the presence of these compounds led to increase protein aggregation. ${ }^{17}$
The main aim of refolding process is to obtain a high quantity of bioactive product at low cost. As described above, protein aggregation in the refolding procedure is the major factor to effect on the amount of bioactive protein. Thus, designing an easy protocol is necessary for this purpose. Unfolded protein causes to generate aggregated protein but folded intermediate is less involved in this process. The preparation of good conditions for forming secondary structure of inclusion bodies during the solubilization step is momentous to decrease aggregation. Ionic and hydrophobic interactions are the 2 major factors to induce aggregation, while the presence of urea at the low concentration or the change of $\mathrm{pH}$, particularly alkaline $\mathrm{pH}$, in the solubilization step help to restore the secondary structures of inclusion bodies following with a better refolding of protein along with high levels of bioactivity. The refolding of oligomeric recombinant proteins from inclusions is more complicated and difficult compared to the single chain proteins. For the oligomeric proteins, it is obligate to firstly refold and form bioactive monomers and then, the fully bioactive oligomeric proteins generate. ${ }^{29,31}$ In addition, huge aggregations occur for refolding of oligomeric proteins specially owning to intermolecular interactions. Therefore, using the mild process to solubilize the inclusion body and also select the protocol to dilute the concentration of proteins and remove impurity could be helpful to decrease the aggregation and enhance the yield of bioactive recombinant proteins. $^{32}$

\section{Conclusions}

The current study has introduced a modified method from the combination of previous methods, dilution and dialysis. In this method, dilution reduced both the impurity and concentration of recombinant proteins, both factors inducing aggregation. In addition, in the low concentration of Urea dialysis causes the prevention of rapid and inappropriate refolding along with removing contaminants. Thus, this event obtains the high yield of refolded and bioactive proteins in comparison with other tested procedures.

Authors' Contributions

All authors contributed equally to this study. 
Conflict of Interest Disclosures

The authors declare they have no conflicts of interest.

\section{Ethical Approval}

This article does not contain any studies with human participants or animals performed by any of the authors.

\section{References}

1. Swartz JR. Advances in Escherichia coli production of therapeutic proteins. Curr Opin Biotechnol. 2001;12(2):195-201. doi:10.1016/ S0958-1669(00)00199-3.

2. Fahnert B, Lilie $H$, Neubauer P. Inclusion bodies: formation and utilisation. Adv Biochem Eng Biotechnol. 2004;89:93-142. doi:10.1007/b93995.

3. Vallejo LF, Rinas U. Strategies for the recovery of active proteins through refolding of bacterial inclusion body proteins. Microb Cell Fact. 2004;3(1):11. doi:10.1186/1475-2859-3-11.

4. Rudolph $\mathrm{R}$, Lilie $\mathrm{H}$. In vitro folding of inclusion body proteins. FASEB J. 1996;10(1):49-56. doi:10.1096/fasebj.10.1.8566547.

5. Clark EDB. Refolding of recombinant proteins. Curr Opin Biotechnol. 1998;9(2):157-163. doi:10.1016/S09581669 (98)80109-2.

6. Walsh G. Biopharmaceutical benchmarks--2003. Nat Biotechnol. 2003;21(8):865-870. doi:10.1038/nbt0803-865

7. Singh SM, Panda AK. Solubilization and refolding of bacterial inclusion body proteins. J Biosci Bioeng. 2005;99(4):303-310. doi:10.1263/jbb.99.303.

8. Tsumoto K, Ejima D, Kumagai I, Arakawa T. Practical considerations in refolding proteins from inclusion bodies. Protein Expr Purif. 2003;28(1):1-8. doi:10.1016/S1046-5928(02)00641-1.

9. De Bernardez Clark E, Schwarz E, Rudolph R. Inhibition of aggregation side reactions during in vitro protein folding. Methods Enzymol. 1999;309:217-236. doi:10.1016/S00766879(99)09017-5.

10. Caceres T, Megharaj M, Venkateswarlu K, Sethunathan N, Naidu R. Fenamiphos and related organophosphorus pesticides: environmental fate and toxicology. Rev Environ Contam Toxicol. 2010;205:117-162. doi:10.1007/978-1-4419-5623-1_3.

11. Farnoosh G, Latifi AM. A review on engineering of organophosphorus hydrolase $(\mathrm{OPH})$ enzyme. J Appl Biotechnol Rep. 2014;1(1):1-10.

12. Latifi AM, Khajeh K, Farnoosh G, Hassanpour K, Khodi S. The cytoplasmic and periplasmic expression levels and folding of organophosphorus hydrolase enzyme in Escherichia coli. Jundishapur J Microbiol. 2015;8(12):e17790. doi:10.5812/ jjm.17790.

13. Raghava S, Barua B, Singh PK, et al. Refolding and simultaneous purification by three-phase partitioning of recombinant proteins from inclusion bodies. Protein Sci. 2008;17(11):1987-1997. doi:10.1110/ps.036939.108.

14. Thapa A, Shahnawaz M, Karki $P$, et al. Purification of inclusion body-forming peptides and proteins in soluble form by fusion to Escherichia coli thermostable proteins. Biotechniques. 2008;44(6):787-796. doi:10.2144/000112728.

15. Farnoosh G, Khajeh K, Latifi AM, Aghamollaei H. Engineering and introduction of de novo disulphide bridges in organophosphorus hydrolase enzyme for thermostability improvement. J Biosci. 2016;41(4):577-588. doi:10.1007/s12038-016-9643-8.

16. Datar RV, Cartwright T, Rosen CG. Process economics of animal cell and bacterial fermentations: a case study analysis of tissue plasminogen activator. Biotechnology (N Y). 1993;11(3):349-357.
17. Maachupalli-Reddy J, Kelley BD, De Bernardez Clark E. Effect of inclusion body contaminants on the oxidative renaturation of hen egg white lysozyme. Biotechnol Prog. 1997;13(2):144-150. doi:10.1021/bp970008l.

18. Tran-Moseman A, Schauer N, De Bernardez Clark E. Renaturation of Escherichia coli-derived recombinant human macrophage colony-stimulating factor. Protein Expr Purif. 1999;16(1):181-189. doi:10.1006/prep.1999.1074.

19. Babbitt PC, West BL, Buechter DD, Kuntz ID, Kenyon GL. Removal of a proteolytic activity associated with aggregates formed from expression of creatine kinase in Escherichia coli leads to improved recovery of active enzyme. Biotechnology (N Y). 1990;8(10):945949. doi:10.1038/nbt1090-945.

20. Wong $\mathrm{HH}, \mathrm{O}^{\prime}$ Neill BK, Middelberg AP. Centrifugal recovery and dissolution of recombinant Gly-IGF-II inclusion-bodies: the impact of feedrate and re-centrifugation on protein yield. Bioseparation. 1996;6(3):185-192.

21. Middelberg AP. Preparative protein refolding. Trends Biotechnol. 2002;20(10):437-443. doi:10.1016/S0167-7799(02)02047-4.

22. Rinas U, Boone TC, Bailey JE. Characterization of inclusion bodies in recombinant Escherichia coli producing high levels of porcine somatotropin. J Biotechnol. 1993;28(2-3):313-320. doi:10.1016/0168-1656(93)90179-Q.

23. Wong $\mathrm{HH}, \mathrm{O}^{\prime}$ Neill BK, Middelberg AP. Cumulative sedimentation analysis of Escherichia coli debris size. Biotechnol Bioeng. 1997;55(3):556-564. doi:10.1002/(sici)10970290(19970805)55:3<556::aid-bit13>3.0.co;2-e.

24. Palmer SM, St John AC. Characterization of a membrane-associated serine protease in Escherichia coli. J Bacteriol. 1987;169(4):14741479. doi:10.1128/jb.169.4.1474-1479.1987.

25. Sugimura K, Higashi N. A novel outer-membrane-associated protease in Escherichia coli. J Bacteriol. 1988;170(8):3650-3654. doi:10.1128/jb.170.8.3650-3654.1988.

26. Batas B, Schiraldi C, Chaudhuri JB. Inclusion body purification and protein refolding using microfiltration and size exclusion chromatography. J Biotechnol. 1999;68(2-3):149-158. doi:10.1016/S0168-1656(98)00197-7.

27. Goldberg ME, Rudolph R, Jaenicke R. A kinetic study of the competition between renaturation and aggregation during the refolding of denatured-reduced egg white lysozyme. Biochemistry. 1991;30(11):2790-2797. doi:10.1021/bi00225a008.

28. West SM, Chaudhuri JB, Howell JA. Improved protein refolding using hollow-fibre membrane dialysis. Biotechnol Bioeng. 1998;57(5):590-599. doi:10.1002/(sici)10970290(19980305)57:5<590::aid-bit11>3.0.co;2-g.

29. Scrofani SD, Fabri LJ, Xu P, Maccarone P, Nash AD. Purification and refolding of vascular endothelial growth factor-B. Protein Sci. 2000;9(10):2018-2025. doi:10.1110/ps.9.10.2018.

30. Garrido F, Estrela S, Alves C, Sanchez-Perez GF, Sillero A, Pajares MA. Refolding and characterization of methionine adenosyltransferase from Euglena gracilis. Protein Expr Purif. 2011;79(1):128-136. doi:10.1016/j.pep.2011.05.004

31. Karumuri NN, Gangireddy SR, Narala VR, Majee SS, Gunwar S, Reddy RC. Simple, rapid, high-purity preparation of recombinant human platelet-derived growth factor-BB. Biotechnol Lett. 2007;29(9):1333-1339. doi:10.1007/s10529-007-9411-9.

32. Upadhyay AK, Singh A, Mukherjee KJ, Panda AK. Refolding and purification of recombinant $\mathrm{L}$-asparaginase from inclusion bodies of $E$. coli into active tetrameric protein. Front Microbiol. 2014;5:486. doi:10.3389/fmicb.2014.00486. 